\title{
AKTIVITAS ANTIKANKER EKSTRAK ETANOL TANAMAN TAPAK LIMAN (Elephantopus scaber L.) TERHADAP SEL T47D MELALUI APOPTOSIS
}

\author{
Panji Ratih Suci $^{1,2 *}$, Nurkhasanah ${ }^{2}$, Nanik Sulistyani ${ }^{2}$ \\ ${ }^{1}$ Akademi Farmasi Mitra Sehat Mandiri \\ ${ }^{2}$ Fakultas Farmasi, Universitas Ahmad Dahlan \\ *Email ${ }^{1}$ : panjiratihsuci13@gmail.com \\ Email $^{2}$ : nurkhas@gmail.com, nanik.sulistyani@gmail.com
}

Artikel diterima: 24 September 2020; Disetujui: 25 Maret 2021

DOI: https://doi.org/10.36387/jiis.v6i1.605

\begin{abstract}
ABSTRAK
Kanker payudara merupakan jenis kanker yang paling mendominasi di Indonesia. Pengobatan tradisional menggunakan tapak liman (Elephantopus scaber L.) sebagai antikanker menjadi pilihan karena mengandung senyawa seperti seskuiterpen . Tujuan penelitian ini untuk mengetahui aktivitas sitotoksik ekstrak etanol tapak liman terhadap sel T47D melalui induksi apoptosis. Metode ekstraksi menggunakan maserasi dengan pelarut etanol 96\%, dilakukan pengujian Flavonoid total dengan menggunakan baku quersetin secara spektrofotometri. uji sitotoksik menggunakan microtetrazoliom (MTT test), dan uji apoptosis menggunakan double staining (ethidium bromide-acrydine orange) dibawah mikroskop fluorescence. Konsentrasi senyawa yang digunakan adalah $1000 \mu \mathrm{g} / \mathrm{ml} ; 500 \mu \mathrm{g} / \mathrm{ml} ; 250 \mu \mathrm{g} / \mathrm{ml}$; $125 \mu \mathrm{g} / \mathrm{ml}, 62,5 \mu \mathrm{g} / \mathrm{ml} ; 31,25 \mu \mathrm{g} / \mathrm{ml}$. Hasil pengujian uji MTT berupa nilai $\mathrm{IC}_{50}$ yang dianalisis menggunakan angka probit dan uji apoptosis dianalisis secara deskriptif. Hasil penelitian menunjukkan persamaan regresi linear $\mathrm{y}=0,0934 \mathrm{x}-$ 0,0292 dengan kadar flavonoid yang dihasilkan sebesar $0,979 \% \mathrm{~b} / \mathrm{b}$ dihitung terhadap quersetin (QE) dengan . dengan metode MTT mempunyai IC 50 sebesar 59 $\mu \mathrm{g} / \mathrm{ml}$, sedangkan pengujian metode double staining ditandai warna hijau terang yang menunjukan mengalami apoptosis awal dan warna orange pada sel yang mengalami apoptosis akhir. Hasil Fragmentasi DNA menunjukkan bahwa ekstrak Tapak Liman menginduksi fragmen DNA. Kesimpulan pada penelitian ini adalah ekstrak tapak liman memiliki potensi aktivitas sitotoksik terhadap sel kanker payudara T47D melalui induksi apoptosis.
\end{abstract}

Kata kunci: Elephantopus scaber, Sitotoksisitas, Apoptosis, Sel T47D

\begin{abstract}
Breast cancer is the most dominant type of cancer in Indonesia. Traditional medicine using tapak liman (Elephantopus scaber L.) as an anticancer becomes an option because it contains compounds such as sesquiterpenes. The purpose of this study was to know the cytotoxic activity of ethanolic extract of tapak liman on T47D cells through induction of apoptosis. The extraction method uses maceration with 96\%. Total flavonoids were tested using quercetin as a spectrophotometric
\end{abstract}


standard. ethanol solvent, cytotoxic test using microtetrazoliom (MTT assay), and apoptosis test using double staining test (ethidium bromide-acrydine orange) under a fluorescence microscope. The results showed the linear regression equation $y=$ $0.0934 x-0.0292$ with the resulting flavonoid levels of $0.979 \% w / w$ calculated against quercetin (QE) The concentration of the compound used was $1000 \mu \mathrm{g} / \mathrm{ml}$; $500 \mu \mathrm{g} / \mathrm{ml} ; 250 \mu \mathrm{g} / \mathrm{ml} ; 125 \mu \mathrm{g} / \mathrm{ml}, 62.5 \mu \mathrm{g} / \mathrm{ml} ; 31.25 \mu \mathrm{g} / \mathrm{ml}$. The MTT assay results are the values of $I C_{50}$ which are analyzed using probit analysis and apoptosis tests which are analyzed descriptively. The results of the research show that the ethanol extract of tapak liman using MTT method has $I C_{50}$ value of $59 \mu \mathrm{g} / \mathrm{ml}$, while the testing of double staining method shows the color of bright green which indicates early apoptosis and the color orange in the cells which undergoing final apoptosis. DNA fragmentation results shows that Tapak Liman extract induces DNA fragments. The conclusion of this study is that tapak liman textract has the potential for cytotoxic activity against T47D breast cancer cells through the induction of apoptosis.

Keyword: Elephantopus scaber, Cytotoxicity, Apoptosis, T47D cells

\section{PENDAHULUAN}

Kanker merupakan sel yang pertumbuhan dan perkembangannya tidak terkontrol dengan melalui proses-proses invasi ke dalam jaringan. Kanker payudara terbentuk pada jaringan sekitar payudara dengan adanya kerusakan gen BRCA1 dan BRCA2 (King, 2000). Adanya kerusakan tersebut mengubah kecepatan proliferasi dan penghambatan apoptosis pada sel T47D (Sukardiman dkk., 2006). Sel T47D merupakan sel kanker hasil diferensiasi lanjut dari sel T-47 yang diisolasi dari payudara seorang wanita penderita kanker. Pada sel T47D mutasi gen dapat mengekspresikan p53 termutasi

(Nurani, 2011).

Apoptosis merupakan program kematian sel dengan tujuan memperbaiki sel pada DNA yang sudah tidak bisa diperbaiki lagi (Ghobrial et al., 2005). Salah satu pengobatan tradisional untuk aktivitas antikanker adalah tapak liman (Elephantopus scaber L.). Tapak liman mengandung senyawa seskuiterpen dan flavonoid yang berkhasiat sebagai antitumor. Penelitian oleh (King, 2000) menyebutkan mengenai beberapa senyawa dari senyawa sesquiterpen (scabertopin (ES-2), isoscabertopin (ES-3), doxylephentopin, deoxyelephantopin (ES-4), 
isodeoxyelephantopin (ES-5) yang diisolasi dari tapak liman (Elephanthopus scaber L.).

Hasil penelitian tentang ekstrak etanol fraksi potreleum eter tapak liman menunjukkan bahwa ekstrak tapak liman mempunyai efek toksik dan memacu mekanisme apoptosis pada sel kanker serviks pada sel Hela pada $\mathrm{IC}_{50} 185 \mu \mathrm{g} / \mathrm{ml}$ (Sukardiman et $a l$, 2006). Perlakuan fraksi kloroform dengan konsentrasi 7,06 $\mu \mathrm{g} \quad / \mathrm{ml}$ menyebabkan kematian sel apoptosis pada stadium akhir nekrosis (Nurani, 2001). Tujuan penelitian ini untuk mengetahui apakah ekstrak etanol daun tapak liman (Elephantopus scaber L. L.) mempunyai aktivitas sitotoksik pada sel T47D. Selain itu juga menentukan potensi ekstrak etanol tapak liman dalam memacu apoptosis sel T47D dengan meihat profil fragmentasi DNA.

\section{METODE PENELITIAN}

\section{Penentuan Kadar Flavonoid Total}

Dibuat larutan baku sekunder quersetin dengan konsentrasi 1 ppm, 2 ppm, 3 ppm, 4 ppm 5 ppm, 6 ppm dan 10 ppm dari larutan baku induk
1000 ppm. Tiap konsentrasi larutan baku sekunder ditambahkan $3 \mathrm{ml}$ metanol, 0,2 ml aluminium klorida $\left(\mathrm{AlCl}_{3}\right) 10 \%$, Na Asetat $0,2 \mathrm{ml} \mathrm{dan}$ aquadest ad $10 \mathrm{ml}$, kemudian diinkubasi pada suhu kamar selama 30 menit. Masing-masing diukur absorbansinya pada spektrofotometri UV-VIS pada $\lambda=440 \mathrm{~nm}$.

Sebanyak 100 mg ekstrak etanol dilarutkan dalam $10 \mathrm{~mL}$ methanol, kemudian diambil $1 \mathrm{~mL}$ sampel ditambahkan $3 \mathrm{~mL}$ methanol, 0,2 $\mathrm{mL} \mathrm{AlCl3} \mathrm{10 \% ,} \mathrm{dan} \mathrm{0,2} \mathrm{mL}$ natrium asetat. Simpan 30 menit pada tempat gelap dengan suhu kamar, diukur absorbansinya dengan panjang gelombang $440 \mathrm{~nm}$. Larutan dibuat 3 kali sebagai ekuivalen quersetin (Ghobrial et al., 2005).

\section{Ekstraksi}

Sebanyak 500 gram serbuk simplisia tapak liman diekstraksi menggunakan pelarut etanol 96\%, dengan metode maserasi kemudian dsaring dan dipekatkan ke dalam alat rotarv evaporator.

\section{Kultur Sel}

Sebanyak 10 mg ekstrak etanol tapak liman dilarutkan dalam $100 \mu 1$ DMSO. 


\section{Uji Sitotoksisitas dan}

\section{Selektivitas}

Sitotoksisitas sel T47D diuji dengan uji MTT. Sel ditanam dengan kepadatan $5 \times 10^{3}$ sel per sumur dengan suhu $37^{\circ} \mathrm{C}$ dalam suasana lembab $5 \% \mathrm{CO}_{2} 95 \%$ udara terlalu tinggi. Sel diinkubasi dengan konsentrasi yang berbeda 1000 $\mu \mathrm{g} / \mathrm{ml} ; 500 \mu \mathrm{g} / \mathrm{ml} ; 250 \mu \mathrm{g} / \mathrm{ml} ; 125$ $\mu \mathrm{g} / \mathrm{ml}, \quad 62,5 \mu \mathrm{g} / \mathrm{ml} ; 31,25 \mu \mathrm{g} / \mathrm{ml}$; ekstrak etanol daun tapak liman selama 24 jam. Setelah inkubasi, media dibuang dan $100 \mu \mathrm{L}$ RPMI dan $10 \mu \mathrm{L}$ MTT (5 mg MTT/mL larutan) ditambahkan ke masing-masing sumur. Plat diinkubasi selama 4 jam. Sel kontrol hanya menerima media tanpa sampel yang diuji. Doksorubisin digunakan sebagai kontrol positif. Kristal formazan yang terbentuk dalam sel yang layak dilarutkan dengan $100 \quad \mu l$ SDSstopper dalam $\mathrm{HCl}$ 0,1 N. Dianalisa dengan panjang gelombang $595 \mathrm{~nm}$ diukur dengan microplate enzymelinked immunosorbent assay (ELISA) reader. Perbedaan absorbansi antara kelompok kontrol yang diberi perlakuan dan yang tidak diberi perlakuan dihitung viabilitas sel.

\section{Acridine Orange-Ethidium}

\section{Bromide Double Stanining}

Sel T47D dimasukkan ke microplate 24 dengan kepadatan $5 \mathrm{x}$ $10^{4} \mathrm{sel} /$ sumuran dalam $1000 \mu \mathrm{l}$ media RPMI dan diinkubasi konfluen selama 24 jam, sampel uji ekstrak etanol tapak liman dimasukkan kedalam sumuran sebesar nilai $\mathrm{IC}_{50}$, kemudian diinkubasi selama 24 jam, Medium diambil, dicuci dengan PBS, sel ditambahkan dengan $10 \mu \mathrm{L}$ working solution akridin orangeetidium bromide. Sel di analisa di bawah mikroskop flouresens (Zeiss MC 80), hasil intepretasi data jika sel hidup akan berfluoresensi warna hijau dan pada Etidium Bromida (EB) sel mati berfluoresensi akan berwarna merah (Wang et al., 2004).

\section{Fragmentasi DNA}

Fragmentasi DNA dimulai dengan memanen sel T47D kemudian diinkubasi selama 24 jam dalam keadaan lingkungan $\mathrm{CO}_{2} 5 \%$ suhu $37^{\circ} \mathrm{C}$. Ektrak etanol tapak liman ditambahkan ke sumuran dengan konsentrasi $\mathrm{IC}_{50}$ dan $1 / 2 \quad \mathrm{IC}_{50}$, kemudian sel diinkubasi selama 24 jam. Sel yang telah ditreatmen kemudian di transfer ke konikel. Sel 
ditambahkan tripsin $0.025 \%$ sebanyak $200 \mu \mathrm{L}$ dan diinkubasi selama 3 menit. Sel yang tekah diinkubasi ditambahkan media kultur RPMI sebanyak $1000 \mu \mathrm{L}$ kemudian sel diresuspensi dan diamati dimikroskop. Sel ditransfer kekonikel dan dicuci dengan PBS sebanyak 500 $\mu \mathrm{L}$. sel disentrifuse dengan kecepatan 600 rpm selama 5 menit kemudian sel siap diisolasi.

Isolasi sel dimulai dengan menambahkan $150 \mu \mathrm{L}$ RBC lisis Buffer kedalam pellet sel dan resuspensi. Sel ditambahkan $200 \mu \mathrm{L}$ FABG Buffer kemudian vortex dengan kecepatan 10.000 rpm selama 5 menit dan dinkubasi 10 menit dengan suhu $70^{\circ} \mathrm{C}$. sel ditambahkan $250 \mu \mathrm{L}$ etanol absolut dan divortex selama 10 menit kemudian sel dipindahkan ke filter tube kemudian disentrifuse dengan kecepatan 10.000 selama 1 menit. Sel ditambahkan 600 $\mu \mathrm{L}$ wash buhher sentrifuse 10.000 rpm selama 1 menit. Sel di tambahan elution buffer sebanyak $100 \mu \mathrm{L}$ kemudian inkubasi pada suhu $37^{0} \mathrm{C}$ selama 10 menit, kemudian Sel disentrifuse dengan kecepatan 10.000 rpm selama 1 menit. Sel dianalisa dengan nanodrop (Nurkhasanah, 2013). Sampel DNA yang diperoleh dianalisis dengan $1 \%$ agarose kemudian di elektroforesis. Setelah elektroforesis, gel diwarnai dengan SYBER Green saya Nucleic Acid Stain (Invitrogen) dan divisualisasikan (Tris - $\mathrm{HCl} 10 \mathrm{mM}$, $\mathrm{pH}$ 7,4 Dan EDTA $1 \mathrm{mM}$ ) dan dideteksi dengan sinar UV (Nurkhasanah, 2013).

\section{PEMBAHASAN}

\section{Pembuatan Ekstrak Etanol} Tapak Liman dengan Metode Maserasi

Hasil ekstrak tapak liman yang didapatkan berupa ekstrak kental yang berwarna hitam pekat dengan \% rendemen sebesar 8,5\%. Rendemen ini sesuai dengan standart baik rendemen tapak liman sebesar 2,7\% .

\section{Uji senyawa Flavonoid Total}

Nilai absorbansi larutan standar kuersetin pada masing-masing konsentrasi diperoleh persamaan garis linear yang nantinya digunakan untuk penetapan kadar flavonoid total pada sampel ekstrak etanol tapak liman berupa grafik kurva konsentrasi versus absorbasi. 


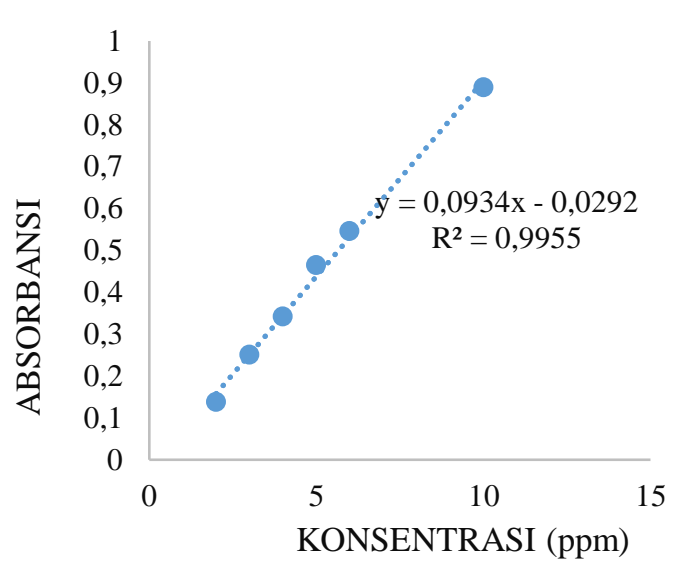

Gambar 1. Kurva kalibrasi larutan standar kuersetin

Dapat dilihat bahwa kurva kalibrasi dengan persamaan regresi untuk absorbasi kuersetin pada konsentrasi 2, 3, 4, 5, 6, dan 10 ppm sebesar $\mathrm{y}=0,0934 \mathrm{x}-0,0292$ larutan standar senyawa fenol dan flavonoid diperoleh hubungan yang linier antara absorbansi dengan konsentrasi. Pada pengukuran flavonoid total dibuat sebanyak tiga replikasi untuk keperluan akurasi data. Sehingga dari hasil penelitian ini diperoleh pengukuran kadar flavonoid total ekstrak etanol tapak liman sebesar $0,979 \% \mathrm{~b} / \mathrm{b}$ dihitung terhadap quersetin $(\mathrm{QE})$.

Tabel 1. Pengukuran kadar flavonoid total ekstrak etanol tapak liman dihitung terhadap quersetin $(\mathrm{QE})$.

\begin{tabular}{cccccc}
\hline Sampel & $\begin{array}{c}\text { Rata- } \\
\text { rata Abs }\end{array}$ & $\begin{array}{c}\text { Kandungan } \\
\text { flavonoid } \\
\text { awal }(\boldsymbol{\mu g} / \mathbf{m L})\end{array}$ & $\begin{array}{c}\text { Faktor } \\
\text { pengenceran } \\
(\mathbf{1 0 X})\end{array}$ & $\begin{array}{c}\text { Kandungan } \\
\text { flavonoid total } \\
\text { (mgQE/g eks) }\end{array}$ & $\begin{array}{c}\text { Rata-rata } \\
\text { flavonoid } \\
\text { total } \mathbf{( \% )}\end{array}$ \\
\hline Sampel 1 & 0,060 & 0,9586 & 9,5860 & 0,00959 & \\
Sampel 2 & 0,064 & 0,9943 & 9,9429 & 0,00994 & 0,979 \\
Sampel 3 & 0,063 & 0,9836 & 9,8358 & 0,00984 & \\
\hline
\end{tabular}

\section{Uji Sitotoksisitas Tapak Liman} terhadap Sel Kanker Payudara T47D dengan Metode MTT

Pengujian sitotoksisitas pada ekstrak etanol tapak liman (Elephanthopus scaber L.) bertujuan untuk mengetahui potensi ketoksikan ekstrak uji tapak liman terhadap sel kanker payudara T47D. Parameter yang digunakan pada uji sitotoksisitas adalah $\mathrm{IC}_{50}$ yang merupakan konsentrasi ekstrak etanol yang dapat menghambat sel sebesar 50\% dari populasi sel. Pengujian sitotoksik menggunakan metode MTT, dimana Ekstrak etanol akan mengabsorsi reagen MTT dan dipecah melalui reaksi reduksi oleh sistem reduktase suksinat tetrazolium dalam rantai respirasi mitokondria menjadi formazan yang berwarna ungu dan tidak larut air tetapi larut dalam SDS 
10\%. Pengujian Sitotoksik menggunakan pelarut DMSO karena baik digunakan untuk senyawa organik maupun anorganik, pelarut ini juga dapat membuat kotoran dan racun terserap (Ahmad et al, 2014). Pengujian MTT harus terdapat kontrol sel yang digunakan untuk mengetahui besarnya suatu besarnya absorbansi yang dihasilkan kehidupan sel dengan sebesar $100 \%$.

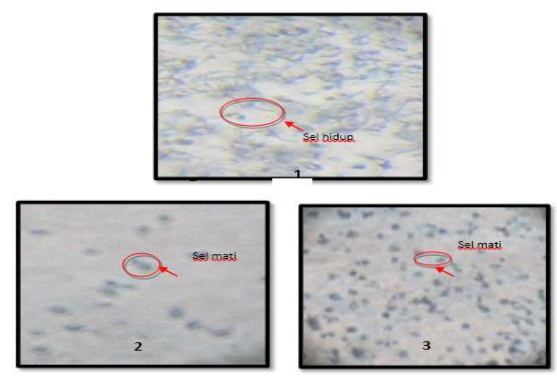

Gambar 2. Kristal formazan yang terbentuk hasil reaksi MTT (1); Kontrol Sel (2); kadar terendah 31,25 $\mu \mathrm{g} / \mathrm{ml}(3)$; kadar tertinggi 1000 $\mu \mathrm{g} / \mathrm{ml}$

Hasil tabel 2 menunjukkan bahwa semakin besar kadar senyawa uji yang diberikan pada suspensi sel maka semakin besar pula persentase kematian sel yang dihasilkan sebaliknya semakin rendah ekstrak etanol tapak liman maka persentase kematian sel juga akan semakin rendah. Hasil penelitian menunjukkan nilai $\mathrm{IC}_{50}$ yang diperoleh adalah $59 \mu \mathrm{g} / \mathrm{mL}$. Berdasaran kriteria yang ditetapkan oleh NCI (National Cancer Institut) menyatakan bahwa suatu ekstrak dinyatakan aktif memiliki aktivitas antikanker apabila memiliki nilai IC $\mathrm{IC}_{50}<30 \mu \mathrm{g} / \mathrm{mL}$, moderate aktif apabila memiliki nilai $\mathrm{IC}_{50}=30 \mu \mathrm{g} / \mathrm{mL}$ dan $\quad \mathrm{IC}_{50}<$ $100 \mu \mathrm{g} / \mathrm{mL}$, dan dikatakan tidak aktif apabila nilai $\mathrm{IC}_{50}>100 \mu \mathrm{g} / \mathrm{mL}$, sehingga dapat disimpulkan ekstrak etanol tapak liman memiliki aktivitas sitotoksik dengan klasifikasi moderate aktif..

Tabel 2. Persen kematian ekstrak etanol tapak liman terhadap sel T47D dengan metode MTT dengan seri kadar $1000 \mu \mathrm{g} / \mathrm{ml}$ sampai $31,25 \mathrm{mg} / \mathrm{mL}$

\begin{tabular}{ccccccccc}
\hline \multirow{2}{*}{ No } & Kadar & \multirow{2}{*}{ Log kadar } & \multicolumn{3}{c}{ \%Kematian } & \multicolumn{3}{c}{ Probit } \\
\cline { 4 - 9 } & $\mathbf{\mu g} / \mathbf{m l}$ & & $\mathbf{R 1}$ & $\mathbf{R 2}$ & $\mathbf{R 3}$ & $\mathbf{R 1}$ & $\mathbf{R 2}$ & $\mathbf{R 3}$ \\
\hline 1 & 1000 & 3,000 & 99,44 & 99,17 & 99,30 & 7,5364 & 7,3954 & 7,4373 \\
2 & 500 & 2,699 & 97,27 & 98,08 & 98,22 & 6,268 & 7,0706 & 7,1015 \\
3 & 250 & 2,398 & 86,58 & 83,06 & 83,60 & 6,1077 & 5,9581 & 5,9782 \\
4 & 125 & 2,097 & 58,96 & 60,99 & 60,18 & 5,2533 & 5,2767 & 5,2585 \\
5 & 62,5 & 1,796 & 55,04 & 35,14 & 52,47 & 5,1257 & 4,6174 & 5,0627 \\
6 & 31,25 & 1,495 & 39,61 & 45,02 & 44,48 & 4,7363 & 4,8704 & 4,8617 \\
\hline
\end{tabular}




\section{Uji Apoptosis Tapak Liman terhadap Sel Kanker Payudara T47D dengan Metode Double \\ Staining}

Metode ini digunakan untuk mendeteksi apoptosis secara cepat. Acridine Orange memberikan pewarnaan baik pada sel hidup maupun pada sel yang mati. Akridine Orange akan menembus semua sel dan membuat inti sel tampak berwarna hijau. Ethidium bromide (EB) akan memberikan warna merah yang menandakan kematian sel karena sel kehilangan integritas membran sitoplasmanya. Pengujian double staining menggunakan kadar pengujian $\mathrm{IC}_{50}$ sebesar $59 \mu \mathrm{g} / \mathrm{ml}$ dengan kontrol sel. Sel hidup akan berfluoresensi hijau terang dalam inti sebagai kondensasi kromatin dan fragmentasi pada inti. Sel yang diberi perlakuan ekstrak etanol tapak liman dengan konsentrasi $\quad \mathrm{IC}_{50}$ memperlihatkan karateristik apoptosis pada tahap akhir yang ditandai dengan warna orange (sel mati) ini dikarenakan ada interaksi dengan ethidium bromide.

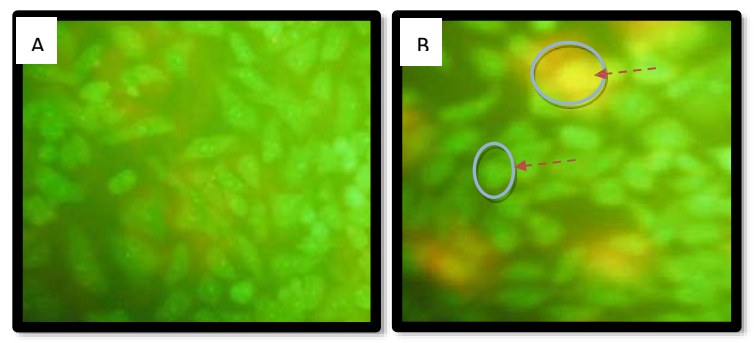

Gambar 3. Hasil Pengecatan sel T47D dengan acridine orange dan ethidium bromide (AO-EB).

Keterangan: a. Kontrol sel, b. senyawa tapak liman $59 \mu \mathrm{g} / \mathrm{ml}$

Berdasarkan hasil pengamatan dengan metode acridin orange dan ethidium bromide (AO-EB) kontrol sel hanya terlihat fluoresensi hijau karena hanya menyerap acridine orange, ethidium bromide tidak dapat masuk pada kontrol sel karena integritas membran sel masih baik. Sedangkan pada kontrol DMSO terlihat fluoresensi hijau dengan sedikit fluoresensi merah hal ini menandakan bahwa pelarut DMSO tidak bersifat sitotoksik terhadap sel. Selain itu pada sel dengan perlakuan juga terlihat adanya fragmentasi inti sel yang kemudian menjadi badanbadan apoptosis. Hal ini menunjukan bahwa perlakuan ekstrak etanol. terhadap sel T47D. Sel yang mengalami apoptosis menyebabkan perubahan permeabilitas membran sel (Nurkhasanah et al., 2015). 


\section{Pengujian Fragmentasi DNA}

Analisis pengujian fragmentasi DNA oleh eksrak etanol daun tapak liman terlihat dari elektroforesis yang ditunjukkan pada media gel agarose. terbentuknya pita DNA pada agarose menunjukkan gambaran dari spesifikasi pengamatan apoptosis yang terlihat pada gambar 2 Gambar tersebut menunjukkan bahwa pada tiap konsentrasi pada ekstrak etanol mengalami fragmentasi DNA. Adanya pita DNA pada gambar tersebut karena adanya aktivitas pembelahan sebagai karakteristik utama dalam mekanisme apoptosis.

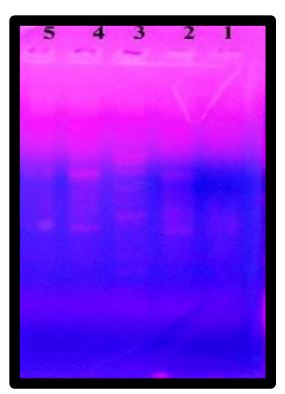

Gambar 4. Hasil Fragmentasi DNA ekstrak etanol Tapak liman (Elephanthopus scaber L.) dengan kadar ekstrak (1) Kontrol sel; (2) 1/8 IC50; (3) Marker; (4) 1/4 IC 50 ;(5) 1/2 $\mathrm{IC}_{50}$

Fragmentasi DNA merupakan tanda khas pada proses apoptosis, yang terjadi karena pengaktifan caspase (terutama caspase-3) atau
DFF45 (DNA Fragmentation Factor45) oleh senyawa apoptotik yang kemudian diikuti oleh aktivasi endonuklease. Pengaktifan DFF45 terjadi dengan pemotongan pada residu D yang kemudian memacu aktivitas DFF40 nuclease, penyebab fragmentasi DNA. Proses apoptosis berbeda dengan nekrosis. Nekrosis merupakan kematian sel yang terjadi pada organisme hidup yang dapat disebabkan oleh injury maupun infeksi. Pada nekrosis terjadi perubahan pada inti yang pada akhirnya dapat menyebabkan inti menjadi lisis dan membrane plasma menjadi rupture. Pada apoptosis terjadi kematian sel yang terprogram dan membran inti tidak ruptur, dan inti mengalami fragmentasi yang kemudian mengirimkan sinyal kepada sel yang berada didekatnya untuk difagosit. Fagositosis oleh makrofag maupun sel di sekelilingnya mengakibatkan fragmentasi DNA menjadi apoptotic body (jisim apoptotik) sehingga Fragmen DNA ini terlihat pada elektroforesis gel agarose (Sharif-Askari, et al., 2001). 


\section{KESIMPULAN}

Ekstrak etanol Tapak Liman (Elephantopus scaber L. L.) mempunyai aktivitas sitotoksik terhadap sel kanker payudara T47D dengan nilai $\mathrm{IC}_{50} 59 \mu \mathrm{g} / \mu \mathrm{l}$., dengan mekanisme induksi apoptosis.

\section{UCAPAN TERIMAKASIH}

Penulis mengucapkan terima kasih kepada Kementrian Riset Teknologi dan Pendidikan Tinggi ataspendanaan Hibah Penelitian Produk Terapan 2016.

\section{DAFTAR PUSTAKA}

Ahmad, A.R.. Sakinah., Wisdawati., Waode Asrifa, 2014, Study of Antioxidant activity and determination of Phenol and Flavonoid content of Pepino's Leaf extract (Solanum muricatum Aiton), International Journal of PharmTech Research, 6, 2: 600-606.

Ghobrial, I. M., Witzig, T. E., Adjei, A. A., 2005, Targeting Apoptosis Pathways in Cancer Therapy, CA: A Cancer. Journal for Clinicians, 55: 178194.

King, R.J.B.,2000, Cancer Biology, 2 nd ed., Pearson Education Limited, London.

Nurani, Laela Hayu, 2011. Uji Sitotoksitas dan Antiproliferatif
Sel Kanker Payudara T47D dan Sel Vero Biji Nigella Sativa, L., Jurnal Ilmiah Kefarmasian, 2, 1, $17-29$.

Nurkhasanah, 2013, Efek Sitotoksik Dan Pemacuan Apoptosis Fraksi Petroleum Eter Ekstrak Etanol Daun Tapak Liman (Elephantopus scaber Linn) terhadap sel Hela, Pharmaciana, 3, 2, 1-7.

Nurkhasanah, Trisnamurti, $\quad$ K.C., Gunaryanti, R.D., Widyastuti, T., 2015, The Screening of Cytotoxic Fraction From Elephantopus scaber Linn against Human Cervical Cancer ( Hela ) Cells. Int. J. Pharma Sci. Res, 6, 1011-1014.

Nurkhasanah, Sulistyani N., Mahdi L, 2017, Chloroform fraction of ethanolic extract of Elephantopus scaber Linn. increase the p53 expression on human breast cancer (T47D) cell line, Pharmaciana: 7, 2.

Sukardiman., Ekasari, W., Hapsari ,P.P., 2006, Aktivitas Antikanker dan Induksi Apoptosis Fraksi Kloroform Daun Pepaya (Carica papaya L.) terhadap Kultur Sel Kanker Mieloma, Media Kedokteran Hewan, 22, 2.

Wang J, Wei Q, Wang CY, Hill D, 2004, Minocycline Up Regulates And Protects Against Cell Death In Mitochondria, J Biol Chem, 279, 199 48-54.

Wang., Nan, S.J.P., Zhong, Y., 2004, Chemical Composition of the Essential Oil of Elephantopus scaber from Southern China. Z., Naturforsch. 59, 327-329. 